\title{
Effect of Calf Diseases on Mortality during Transport for Slaughter
}

\author{
V. VEČEREK ${ }^{1}$, V. ŠÍMOVÁ ${ }^{1}$, M. MALENA ${ }^{2}$, E. VOSLÁŘOVÁ $^{1}$, M. MALENA jr. $^{2}$ \\ ${ }^{1}$ University of Veterinary and Pharmaceutical Sciences Brno, Czech Republic \\ ${ }^{2}$ State Veterinary Administration, Czech Republic
}

Received April 10, 2006

Accepted June 30, 2006

\begin{abstract}
Večerek V., V. Šímová, M. Malena, E. Voslářová, M. Malena jr.: Effect of Calf Diseases on Mortality during Transport for Slaughter. Acta Vet. Brno 2006, 75: 625-630.

The aim of this study was to determine the general effect of calf diseases on the mortality rate in connection with a journey distance and, furthermore, to determine the tendency of development in this field. During the period of 1997 - 2004 inspectors of the State Veterinary Administration in the Czech Republic recorded the number of healthy calves transported for standard slaughter and numbers of calves that died in connection with this transport; furthermore, they recorded numbers of diseased calves transported for emergency slaughter and numbers of calves that died in connection with this transport. The calf mortality rate in connection with transport for standard slaughter and in connection with transport for emergency slaughter was $0.026 \%(29 / 113144)$ and $3.266 \%$ (2260/69207), respectively. The mortality rate during transport for emergency slaughter is considerably higher, an expression in the form of a ratio index is 127.4. The total number of calf deaths during transport for slaughter significantly increased $(p<0.01)$ due to calf diseases. The effect of the journey distance on calf mortality in connection with transport was manifested as follows: during transport up to $50 \mathrm{~km}$ the recorded mortality rate was $0.019 \%$ for standard slaughter and $3.029 \%$ for an emergency one. In case of a longer journey distance, up to $200 \mathrm{~km}$, a higher mortality rate was detected, namely $0.110 \%$ for standard slaughter and $5.177 \%$ for an emergency one. Due to diseases the number of calf deaths during transport up to 50, 100 and $200 \mathrm{~km}$ significantly increased $(p<0.01)$. A long-term tendency concerning increase or decrease of calf disease effect on the mortality rate in calves during transport for slaughter depending on individual years of the period monitored was not proved. Calf disease significantly decreases calf welfare during their transport for slaughter and considerably increases number of calves that died in connection with transport for slaughter.
\end{abstract}

Transport stress, welfare, emergency slaughter, standard slaughter, journey distance

Animal health is one of the factors affecting the standard of animal welfare. Welfare during transport of animals for slaughter is influenced by transport stress, and significant transport stress can result even in the death of the animal. Thus, the number of animals that died in connection with their transport for slaughter can be an indicator of the welfare during transport. Diseases of animals decrease animal welfare during their transport for slaughter. Therefore diseases can influence the mortality rate of animals during their transport for slaughter. From the viewpoint of animal species and categories these problems are of particular importance in calves, because diseased calves represent a significant part of calves transported for slaughter.

Stress of calves increases during their transport for slaughter. Conditions influencing the level of stress are as follows: regrouping, handling during loading, driving performance, air quality in the vehicle, transport time, handling during unloading, lairage time. Grig or et al. (2001) investigated the effects of space allowance on the physiological, and behavioural response of calves during transport. Van de Water et al. (2003), studying the effect of transport on the physiology of calves, states also the effect of the position of calves on the truck. Steinhardt (2003) studied the effect of transport stress in cattle and intensified

Address for correspondence:

Prof. MVDr. Vladimír Večerek, CSc.

University of Veterinary and Pharmaceutical Sciences

Palackého 1-3

61242 Brno, Czech Republic
Tel.: +420541562770

Fax: +420 541562790

e-mail: vecerekv@vfu.cz

http://www.vfu.cz/acta-vet/actavet.htm 
human - animal contact on the reactions of animals exposed to transport process. Lensink et al. (2000) monitored the influence of gentle contacts performed by stockpersons on the welfare of calves. Lensink et al. (2001a) studied behavioural reaction of calves, having previous experience with humans, during transport. Influence of the farmers' behaviour on the calves' reactions to transport was investigated by Lensink et al. (2001b). Stein hardt and Thielscher $(2000,2003,2005 a)$ focused on the reaction of dairy calves exposed to transport stress, namely from the viewpoint of rearing conditions, husbandry systems, and different breeds.

Fazio and Ferlazzo (2003) evaluated stress during transport. Transport stress of calves causes, in particular changes of ethological indicators (Broom 2003), physiological variables (Steinhardt and Thielscher 2000), haematological variables (Steinhardt and Thielscher 2005a,b), biochemical, metabolic and hormonal variables (Steinhardt and Thielscher 2002, 2003). In their study, Odore et al. (2004) documented the effect of transportation on blood hormone levels and lymphocyte glucocorticoid and beta-adrenergic receptor concentrations in calves.

Deteriorated transport conditions may lead to animal damage. Pištěková et al. (2004) referred to the occurrence of immobile cattle resulting from inadequate handling during transport for slaughter. Mechanical damage of animals during transport and the development of processes due to transport stress of cattle can project to the veterinary decision-making on meat edibility and can increase occurrence of unfit meat due to its deviation from sensory properties as being referred to by Večerek et al. (2003). Better transport conditions can decrease stress of calves during transport for slaughter and, as a consequence, improve indicators of veal meat quality, as referred to by Len sink et al. $(2000,2001 \mathrm{~b})$ and $\mathrm{V}$ an de Water et al. (2003).

The aim of our study was to assess the total effect of diseases on the calf mortality rate during transport for slaughter, to determine the effect of diseases on the calf mortality rate depending upon distance and, furthermore, to determine the development tendency of the effect of diseases on the calf mortality rate during transport for slaughter.

\section{Materials and Methods}

The effect of calf diseases on their mortality rate during transport for slaughter was monitored within the period 1997 - 2004. Inspectors of the State Veterinary Administration of the Czech Republic recorded the number of healthy calves transported for standard slaughter and the number of calves that died in connection with this transport, i.e. the number of calves that died directly in a transport vehicle or at slaughterhouse after transport. Furthermore, they recorded the number of diseased calves transported for emergency slaughter and the number of calves that died in connection with this transport.

The effect of calf diseases on the mortality rate during transport for slaughter was monitored by comparing calf death frequency during transport for standard slaughter and calf death frequency during transport for emergency slaughter. An index was calculated as a ratio of the relative frequency of calf deaths during transport for emergency slaughter to the relative frequency of calf deaths during transport for standard slaughter.

The effect of calf diseases on the calf mortality rate during transport for slaughter in connection with the journey distance was monitored by comparing calf death frequency during transport for standard slaughter and calf death frequency during transport for emergency slaughter for the following journey distances: up to $50 \mathrm{~km}, 51 \mathrm{~km}$ to $100 \mathrm{~km}, 101 \mathrm{~km}$ to $200 \mathrm{~km}, 201 \mathrm{~km}$ to $300 \mathrm{~km}$, over $300 \mathrm{~km}$. For the individual journey distances an index was calculated as a ratio of the relative frequency of calf deaths during transport for emergency slaughter to the relative frequency of calf deaths during transport for standard slaughter.

The development tendency of the effect of calf diseases on their mortality rate during transport for slaughter was determined on the basis of the comparison of total frequencies of calf deaths during transport for standard slaughter and total frequencies of calf deaths during transport for emergency slaughter in the particular years of the period monitored. For the individual years an index was calculated as a ratio of the relative frequency of calf deaths during transport for emergency slaughter to the relative frequency of calf deaths during transport for standard slaughter. From index values for individual years the development tendency concerning the effect of calf diseases on the calf mortality rate during transport for slaughter was derived.

An index value higher than 1.00 indicates the effect of calf diseases on the mortality rate during transport for slaughter, the value 1.00 indicates a state when calf diseases have no effect on the mortality rate during transport 
for slaughter, and a value lower than 1.00 indicates a state when calf diseases have no effect on the mortality rate during transport for slaughter.

Results of absolute and relative frequencies were processed by the computer software Excel using a statistical computing module. The statistical processing was performed by $\chi^{2}$ - test using the computer program Unistat 5.1 .

\section{Results}

The effect of calf diseases on the mortality rate during transport for slaughter was monitored on the basis of the comparison of the frequencies of calf deaths during transport for standard slaughter and frequencies of calf deaths during transport for emergency slaughter as stated in Table 1.

Table 1. Total number of calf deaths in connection with transport for standard and emergency slaughter

\begin{tabular}{|c|c|c|c|c|c|c|c|c|}
\hline Period & \multicolumn{3}{|c|}{$\begin{array}{c}\text { Transport } \\
\text { for standard slaughter }\end{array}$} & \multicolumn{3}{|c|}{$\begin{array}{c}\text { Transport } \\
\text { for emergency slaughter }\end{array}$} & \multirow[b]{2}{*}{$\mathrm{B} / \mathrm{A}$} & \multirow{3}{*}{$p$} \\
\hline \multirow{3}{*}{$1997-2004$} & & & $\mathrm{~A}$ & & & $\mathrm{~B}$ & & \\
\hline & $\begin{array}{l}\text { Transport } \\
\text { (number) }\end{array}$ & $\begin{array}{c}\text { Death } \\
\text { (number) }\end{array}$ & $\begin{array}{c}\text { Mortality } \\
(\%)\end{array}$ & $\begin{array}{l}\text { Transport } \\
\text { (number) }\end{array}$ & $\begin{array}{c}\text { Death } \\
\text { (number) }\end{array}$ & $\begin{array}{c}\text { Mortality } \\
(\%)\end{array}$ & Index & \\
\hline & 113144 & 29 & 0.026 & 69207 & 2260 & 3.266 & 127.4 & $* * 0.000$ \\
\hline
\end{tabular}

$* *=p<0.01$

It follows from Table 1 that, in calves, a death rate for the whole period was, in connection with transport for standard slaughter, $0.026 \%$ and, in connection with transport for emergency slaughter, $3.266 \%$. Thus, in numbers of calf deaths connected with transport, there is a basic difference between transport of healthy calves for standard slaughter and transport of diseased calves for emergency slaughter. The latter is considerably higher, namely expressed in the form of the ratio index 127.4. Thus, due to diseases, the total number of calf deaths during transport for slaughter significantly increased $(p<0.01)$.

For the particular journey distances the effect of calf diseases on the mortality rate during transport for slaughter was monitored on the basis of the comparison of the calf death frequency during transport for standard slaughter and calf death frequency during transport for emergency slaughter, as presented in Table 2.

Table 2. Number of calf deaths in connection with transport for standard and emergency slaughter depending on the journey distance

\begin{tabular}{|c|c|c|c|c|c|c|c|c|}
\hline & \multicolumn{3}{|c|}{$\begin{array}{c}\text { Transport } \\
\text { for standard slaughter }\end{array}$} & \multicolumn{3}{c|}{$\begin{array}{c}\text { Transport } \\
\text { for emergency slaughter }\end{array}$} & \multirow{2}{*}{ B/A } & \multirow{2}{*}{$p$} \\
\cline { 1 - 8 } $\begin{array}{c}\text { Journey } \\
\text { distance } \\
(\mathrm{km})\end{array}$ & $\begin{array}{c}\text { Transport } \\
\text { (number) }\end{array}$ & $\begin{array}{c}\text { Death } \\
\text { (number) }\end{array}$ & $\begin{array}{c}\text { Mortality } \\
(\%)\end{array}$ & $\begin{array}{c}\text { Transport } \\
\text { (number) }\end{array}$ & $\begin{array}{c}\text { Death } \\
\text { (number) }\end{array}$ & $\begin{array}{c}\text { Mortality } \\
(\%)\end{array}$ & Index & \\
\hline$<50$ & 85902 & 16 & 0.019 & 51967 & 1574 & 3.029 & 162.6 & $0.000 * *$ \\
\hline $51-100$ & 18161 & 4 & 0.022 & 15558 & 604 & 3.882 & 176.3 & $0.000^{* *}$ \\
\hline $101-200$ & 5446 & 6 & 0.110 & 1584 & 82 & 5.177 & 47.0 & $0.000^{* *}$ \\
\hline $201-300$ & 3481 & 3 & 0.086 & 96 & 0 & 0.000 & 0.0 & 0.774 \\
\hline$>300$ & 154 & 0 & 0.000 & 2 & 0 & 0.000 & 1.0 & 1.000 \\
\hline
\end{tabular}

$* *=\mathrm{p}<0.01$

It follows from Table 2 that the effect of the journey distance on calf deaths in connection with transport for standard slaughter was manifested as follows: in case of the journey distance up to $50 \mathrm{~km}$ the recorded mortality rate was $0.019 \%$ and, in case of the longer 
journey distance up to $200 \mathrm{~km}$ the recorded mortality rate was markedly higher, namely up to $0.110 \%$. Generally, the following effect of journey distance on calf deaths in connection with transport for emergency slaughter was found: in the journey distance up to $50 \mathrm{~km}$ the recorded mortality rate was $3.029 \%$, in the longer journey distance up to $200 \mathrm{~km}$ the recorded mortality rate was considerably higher, namely up to $5.177 \%$. Thus, in case of journey distances up to $200 \mathrm{~km}$, there is a basic difference in numbers of calf deaths in connection with transport, namely between transport of healthy calves for standard slaughter and transport of diseased calves for emergency slaughter, when number of calf deaths during transport for emergency slaughter is considerably higher, namely expressed by the index 162.6 for the journey distance up to $50 \mathrm{~km}$, by the index 176.3 for the journey distance 51 $\mathrm{km}$ up to $100 \mathrm{~km}$, and by the index 47.0 for the journey distance $101 \mathrm{~km}$ up to $200 \mathrm{~km}$. Thus, for all journey distances up to $200 \mathrm{~km}$, the number of calf deaths during transport for slaughter was statistically highly significantly $(p<0.01)$ increased due to diseases of calves. Transport of calves for standard slaughter exceeding the distance of $200 \mathrm{~km}$ is not usual. Such transport is realized under conditions when deaths occur only rarely. Transport of calves for emergency slaughter exceeding the distance of $200 \mathrm{~km}$ is done sporadically and no deaths were recorded during such transport.

The development tendency of the calf disease effect on the mortality rate of calves during transport for slaughter was determined using a comparison of total calf death frequencies during transport for standard slaughter and total calf death frequencies during transport for emergency slaughter in particular years of the period monitored. This tendency is shown in Table 3.

Table 3. Tendency in numbers of calf deaths in connection with transport for standard slaughter and emergency slaughter

\begin{tabular}{|c|c|c|c|c|c|c|c|c|}
\hline \multirow{2}{*}{ Year } & \multicolumn{3}{|c|}{$\begin{array}{c}\text { Transport } \\
\text { for standard slaughter }\end{array}$} & \multicolumn{3}{c|}{ Transport } & \multirow{2}{*}{ for emergency slaughter } & \\
\cline { 2 - 9 } & & & $\mathrm{A}$ & & & $\mathrm{B}$ & $\mathrm{B} / \mathrm{A}$ \\
\cline { 2 - 9 } & $\begin{array}{c}\text { Transport } \\
\text { (number) }\end{array}$ & $\begin{array}{c}\text { Death } \\
\text { (number) }\end{array}$ & $\begin{array}{c}\text { Mortality } \\
(\%)\end{array}$ & $\begin{array}{c}\text { Transport } \\
\text { (number) }\end{array}$ & $\begin{array}{c}\text { Death } \\
\text { (number) }\end{array}$ & $\begin{array}{c}\text { Mortality } \\
(\%)\end{array}$ & Index & \\
\hline 1997 & 25729 & 9 & 0.035 & 10643 & 332 & 3.119 & 89.2 & $0.000^{* *}$ \\
\hline 1998 & 17893 & 2 & 0.011 & 9590 & 293 & 3.055 & 273.3 & $0.000^{* *}$ \\
\hline 1999 & 15804 & 3 & 0.019 & 10249 & 310 & 3.025 & 159.3 & $0.000^{* *}$ \\
\hline 2000 & 9681 & 5 & 0.052 & 8881 & 316 & 3.558 & 68.9 & $0.000^{* *}$ \\
\hline 2001 & 10385 & 2 & 0.019 & 8882 & 543 & 6.113 & 317.4 & $0.000^{* *}$ \\
\hline 2002 & 11862 & 4 & 0.034 & 8764 & 258 & 2.944 & 87.3 & $0.000^{* *}$ \\
\hline 2003 & 11161 & 1 & 0.009 & 7213 & 208 & 2.884 & 321.8 & $0.000^{* *}$ \\
\hline 2004 & 10629 & 3 & 0.028 & 4985 & 0 & 0.000 & 0.0 & 0.236 \\
\hline
\end{tabular}

$* *=p<0.01$

It follows from Table 3 that an index expressing a ratio of total frequencies of calf deaths during transport for standard slaughter to total frequencies of calf deaths during transport for emergency slaughter in particular years of the monitored period varied from 68.9 to 321.8, excepting year 2004, when the index value amounted to 0.0. Index values did not show a long-term tendency of increase or decrease depending on particular years of the period monitored. The considerable effect of calf diseases on the calf mortality rate in connection with their transport for slaughter was found in all years of the monitored period, excepting year 2004. In 2004 no calf death occured during transport for emergency slaughter which is connected with a legislative amendment. Since 2004 the legislation has not allowed the transport of a diseased animal from a farm to the slaughterhouse, provided that the health state of the animal can result in suffering during transport. 


\section{Discussion}

Generally, transport for slaughter increases the stress of calves. The stress level is influenced by conditions, under which calf transport is realized. These conditions are as follows: regrouping, handling during loading and unloading, driving performance, air quality in the vehicle, transport time, lairage time. Grigor et al. (2001) consider as important also the space allowance during transport. Van de Water et al. (2003) also mention the effect of the position of calf on the truck. Steinhardt (2003) mentions the effect of the intensified human - animal contact in the farm, likewise Len sink et al. (2000) mention the gentle contact with stockperson and Lensink et al. (2001a,b) also mention previous experience with humans and farmer's behaviour towards calves as a factor reducing calf stress during their transport. Steinhardt and Thielscher (2000, 2003, 2005a) state the effect of husbandry systems and different breeds. Broom (2003) emphasized animal health as a factor of animal welfare. Thus, calf disease decreases animal welfare during their transport for slaughter. The mortality rate of calves connected with transport for slaughter may indicate a strong breach of welfare during transport of calves. However, the determined level of the calf mortality rate in connection with the transport for standard slaughter was overall lower than the number of transport deaths in pigs reported by Večerek et al. (2006).

When monitoring the effect of disease on welfare during transport of calves for slaughter we have found the basic difference in the mortality rate during the transport of healthy and diseased calves. Disease of calves increased the total number of calf deaths during transport for slaughter. Our statement is supported by Broom (2003), who considers animal health as one of the welfare factors.

We recorded that the mortality rate of calves increases in connection with growing journey distance up to $200 \mathrm{~km}$ in both healthy and diseased calves. Disease of calves, in cases of all journey distances up to $200 \mathrm{~km}$, increased significantly the calf mortality rate during transport for slaughter. This finding is in accordance with the conclusion stated by Fazio and Ferlazzo (2003) that a reaction of animals to stressors depends on the duration and intensity of the stressors. Steinhardt and Thielscher (2000, 2002, 2003, 2005a,b), Odore et al. (2004) document modifications in stress indicators during transport of calves.

Deteriorated welfare of calves during transport can have impact on calf carcasses and meat quality as stated by Pištěková et al. (2004) and Večerek et al. (2003). Lensink et al. (2000, 2001b) and V an de Water et al. (2003) referred to an improvement of veal quality indicators in consequence of a stress reduction in calves during transport for slaughter.

\section{Vliv onemocnění telat na úhyny při přepravě na porážku}

Cílem práce bylo zjistit celkový vliv onemocnění na počty úhynů telat př̀i přepravě na porážku, zjistit vliv onemocnění na počty úhynů telat v souvislosti s přepravní vzdáleností a dále zjistit trend ve vývoji vlivu onemocnění na počty úhynů telat př̀i přepravě na porážku. Inspektoři Státní veterinární správy v České republice v období 1997 až 2004 zaznamenávali počty zdravých telat přepravovaných na normální porážku a počty uhynulých telat $\mathrm{v}$ souvislosti $\mathrm{s}$ touto přepravou, a dále zaznamenávali počty telat $\mathrm{s}$ onemocněním přepravovaných na nutnou porážku a počty uhynulých telat v souvislosti s touto přepravou. Byla zjištěna úroveň úhynů telat za celé období v souvislosti s přepravou na normální porážku 0,026 \% (29/113144) a v souvislosti s přepravou na nutnou porážku 3,266 \% (2260/69207). Počet úhynů telat při přepravě na nutnou porážku byl výrazně vyšší, a to vyjádřen indexem poměru 127,4 . Vlivem onemocnění telat se tak celkový počet úhynů telat při přepravě na porážku statisticky významně zvýšil $(p<0,01)$. Vliv přepravní vzdálenosti na úhyny telat $\mathrm{v}$ souvislosti $\mathrm{s}$ přepravou se projevil tak, že při přepravní vzdálenosti do $50 \mathrm{~km}$ byla zjištěna úroveň úhynů pro normální porážku 0,019\% a pro nutnou porážku 
$3,029 \%$ a př̀i delší přepravní vzdálenosti do 200 km byla zjištěna podstatně vy̌̌ší úroveň úhynů a to pro normální porážku $0,110 \%$ a pro nutnou porážku $5,177 \%$. Vlivem onemocnění telat se celkový počet úhynů při přepravě na porážku do vzdálenosti 50, 100 a 200 km statisticky významně zvýšil $(p<0,01)$. Nebyl zjištěn dlouhodobý trend vzestupu nebo poklesu vlivu onemocnění telat na počty úhynů telat př́i přepravě na porážku v závislosti na jednotlivých letech sledovaného období. Onemocnění telat významně zhoršuje welfare telat při jejich přepravě na jatky a výrazně zvyšuje počty telat uhynulých $\mathrm{v}$ souvislosti s přepravou na jatky.

\section{Acknowledgements}

Supported by the Research Project No. MSM6215712402 Veterinary aspects of food safety and quality.

\section{References}

BROOM DM 2003: Transport stress in cattle and sheep with details of physiological, ethological and other indicators. Dtsch Tierarztl Wochenschr 110: 83-86

FAZIO E, FERLAZZO A 2003: Evaluation of stress during transport. Vet Res Commun 27: 519-524

GRIGOR PN, COCKRAM MS, STEELE WB, LE SUEUR CJ, FORSYTH RE, GUTHRIE JA, JOHNSON AK, SANDILANDS V, REID HW, SINCLAIR C, BROWN HK 2001: Effects of space allowance during transport and duration of mid-journey lairage period on the physiological, behavioural and immunological responses of young calves during and after transport. Anim Sci 73: 341-360

LENSINK BJ, FERNANDEZ X, BOIVIN X, PRADEL P, LE NEINDRE P, VEISSIER I 2000: The impact of gentle contacts on ease of handling, welfare, and growth of calves and quality of veal meat. J Anim Sci 78: 12191226

LENSINK BJ, RAUSSI S, BOIVIN X, PYYKKONEN M, VEISSIER I 2001a: Reactions of calves to handling depend on housing condition and previous experience with humans. Appl Anim Behav Sci 70: 187-199

LENSINK BJ, FERNANDEZ X, COZZI G, FLORAND L, VEISSIER I 2001b: The influence of farmers' behavior on calves' reactions to transport and quality of veal meat. J Anim Sci 79: 642-652

ODORE R, D'ANGELO A, BADINO P, BELLINO C, PAGLIASSO S, RE G 2004: Road transportation affects blood hormone levels and lymphocyte glucocorticoid and beta-adrenergic receptor concentrations in calves. Vet J 168: $297-303$

PIŠTĚKOVÁ V, OŠT̃ÁDALOVÁ I, SEDLÁKOVÁ J, TOMANOVÁ P, BEDÁŇOVÁ I 2004: Emergency slaughter of cattle due to immobility. Acta Vet Brno 73: 533-538

STEINHARDT M 2003: Transport stress in young cattle from a suckler herd. Effects of acclimatization and intensified human-animal contact on the reactions of animals exposed to transport process - Plasma cortisol, biochemical, hematological variables, minerals and heart rate. Tierarztl Umsch 58: 304-309

STEINHARDT M, THIELSCHER HH 2000: Reactions of dairy calves exposed to transport stress at 60 days of postnatal age. Effects of rearing conditions and development quality on physiological variables and their changes. Dtsch Tierarztl Wochenschr 107: 59-65

STEINHARDT M, THIELSCHER HH 2002: Transport stress in young calves. Effects of animal breed and of husbandry system on biochemical, metabolic and hormonal variables. Tierarztliche Praxis Ausgabe Grosstiere Nutztiere 30: 369-377

STEINHARDT M, THIELSCHER HH 2003: Transport stress in monozygotic twin calves - Effects of husbandry systems on metabolic and hormonal variables. Tierarztl Umsch 58: 645-650

STEINHARDT M, THIELSCHER HH 2005a: Transport stress in young calves. Effects of animal breed and husbandry system on heart rate, hematological variables, blood lactate and acid-base balance. Tierarztliche Praxis Ausgabe Grosstiere Nutztiere 33: 28-36

STEINHARDT M, THIELSCHER HH 2005b: The effect of haemoglobin content of blood on the reactions of suckler calves exposed to short haul road transport and temporary separation from herd mates. Tierarztl Umsch 60: $356-358$

VAN DE WATER G, VERJANS F, GEERS R 2003: The effect of short distance transport under commercial conditions on the physiology of slaughter calves, $\mathrm{pH}$ and colour profiles of veal. Livest Prod Sci 82: 171-179

VEČEREK V, KOZÁK A, MALENA M, TREMLOVÁ B, CHLOUPEK P 2003: Veterinary meat inspection of bovine carcasses in the Czech Republic during the period of 1995 - 2002. Vet Med-Czech 48: 183-189

VEČEREK V, MALENA M, MALENA M jr., VOSLÁŘOVÁ E, CHLOUPEK P 2006: The impact of the transport distance and season on losses of fattened pigs during transport to the slaughterhouse in the Czech Republic in the period from 1997 to 2004. Vet Med-Czech 51: 21-28 